\title{
Voiko kontemplatiivinen pedagogiikka haastaa konsumerismin?
}

\author{
$\stackrel{y}{2 y}$ \\ Kontemplatiivisilla harjoitteilla tuodaan idän meditatiivisia \\ tietoisuustaitoja esimerkiksi työelämään ja kouluympäristöön. \\ Tietoinen ja hyväksyvä läsnäolo eli mindfulness opettaa \\ tyytyväisyyttä nykyhetkeen ja tarjoaa myös mahdollisuuden \\ irtaantua kuluttajakansalaisen identiteetistä.
}

IHMISK UNNALLA on käytössään tietoa ennennäkemätön määrä, mutta tiedämme Georg Henrik von Wrightin (1992) tavoin, että tieto ja tiede voidaan panna palvelemaan myös haitallisia tarkoitusperiä. Tiede on menestynyt etsiessään totuutta, mutta "uusien arvojen etsiminen ei ole johtanut menestyksellisiin tuloksiin”. Perinteisen uskontoon perustuvan arvomaailman rapistuttua tilalle on tullut arvotyhjiö tai jopa arvonihilismi, jotka kertovat von Wrightin mukaan kulttuurimme hämmennyksestä ja epävarmuudesta. (von Wright 1992, 161, 188.) Liiallinen yhtäaikaisen sisällön lisääminen tietoisuuteen voikin jopa hämärtää ja hämmentää mieltä niin, että sen on vaikea orientoitua viisaasti (Jung 1991, 21). Tieto ei tee automaattisesti viisaaksi, vaan tarvitaan myös viisautta ja ymmärrystä.

Miten ihmisen tietoisuus sitten voi tulla entistä viisaammaksi? Miten suunnistautua oikeisiin suun- tiin? Nämä kysymykset kuuluvat perenniaalisen, eli ikuisen filosofian kysymyksiin, jotka askarruttavat ihmistä aikakaudesta ja kulttuurista toiseen. Nykyaikaistetusti viisauden ja suunnistautumisen perenniaalisista kysymyksistä voidaan puhua myös erilaisten "tietoisuustaitojen"1 kehittymisenä, kuten englannin mindfulness-sana on suomennettu. Tietoisuustaidoissa korostuu kyky hyväksyvään, myötätuntoiseen ja tietoiseen läsnäoloon sekä mieleen, joka on tyyni, kirkas, havaintokykyinen ja juurtunut todellisuuteen. Nämä voidaan nähdä myös aikakaudesta toiseen viisaan ihmisen tunnusmerkkeinä, kasvatusideaaleina.

Perenniaalisten kysymysten filosofia tähtää siihen, että ihminen saa otteen olemassaoloonsa sekä yhteyden maailmaan vieraantuneisuuden ja ulkokohtaisuuden sijaan (Koski, Vainion 2001 mukaan). Tietoisuustaidot voivatkin auttaa vieraantumisen voittamisessa ja myös auttaa yksilöä suunnistautumaan 
viisaammin. Pierre Hadotin (2010) tulkinta antiikin filosofiasta henkisenä harjoituksena ja elämäntapana paljastaa, että länsimaisen kulttuurin älylliset juuret painottivat kontemplatiivisen pedagogiikan kaltaisia kehon ja mielen harjoituksia hyveen ja viisauden oppimiseksi. Uudelle ajalle asti myös akateeminen filosofia kytkeytyi käytännöllisiin elämän ja tietoisuuden taitoihin, eikä vain teoriaan elämästä ja maailmasta (Hadot 2010).

Arvostelukykyisen viisauden oppiminen on tullut ajankohtaiseksi, kun konsumerismista on tullut Marglinin mukaan ihmisen keino ratkaista eksistentiaalisia ongelmiaan (Marglin 2009, 222). Arvotyhjiöön ja hämmennykseen haetaankin lohtua kuluttamisesta, jonka uskotaan tekevän ihmiselämästä onnellisempaa. Degrowth-keskustelussa on esimerkiksi haettu vastauksia konsumerismin ja rajattoman kasvun haasteisiin rajallisella planeetalla, sillä jo ennestään taloudellisesti hyvinvoivalle ihmiselle lisä- tai kerskakulutus ei tuo sanottavaa lisää koettuun onnellisuuteen (Latousche 2010). Uusiutuvien ja uusiutumattomien luonnonvarojen väheneminen asettaa haasteita sekä yhteiskunnan instituutioille että kasvatukselle, sillä niukkuus, joka aiheuttaa kilpailua, voi aiheuttaa tunnetusti myös sotaa (Homer-Dixon 1999), jos resursseja ei onnistuta jakamaan yhteistyössä (Pulkki 2010).

Kun talous on irronnut materiaalisesta perustastaan, ihmisen ja luonnon välisestä aineenvaihdunnasta, "edessä on valtava maailmankuvallinen oppimistehtävä" (Bardy 2011,334). Entistä selvemmäksi käy, että moraalisubjektiviteetista ei voi puhua globaalien ympäristökriisien aikana irrallaan ekologisesta tietoisuudesta (Värri \& Saari 2012). Marjatta Bardyn (2011, 347) mukaan "tarvitaan hallintapyrkimysten hillintää $[\ldots]$, vastavuoroisuuden tajua ja luonnon rajoihin sopeutuvaa yhteisvastuullisuutta" sekä "arvostavaa maailmankuvaa ohjaamaan elämänmuodon muutoksia ja teknologisia ratkaisuja”.

Kun ihmisen valta luonnon yli on kasvanut räjähdysmäisesti, tarvitaan ihmisen tietoisuuden vastaavaa laajenemista. Yksi olennainen näkökulma konsumerismin haasteeseen onkin tietoisuustaitojen oppiminen. Tällaisten taitojen laajamittainen oppiminen voisi toimia myös ruohonjuuritason vaikuttajana yhteiskunnallisen muutoksen kätilöimisessä. Yhteis- kunnallinen ja yksilötason muutos kietoutuvat vuorovaikutuksellisesti toisiinsa ja toinen näkökulma ilman toista on puutteellinen.

Tietoisuustaitojen kehittymiseen yhteiskunnallisesti vaikuttavaksi voimaksi tarvitaan kontemplatiivista pedagogiikkaa, jossa erilaisia meditatiivisluontoisia harjoituksia sovelletaan koulukontekstiin. Kun vallitseva käsitys hyvästä ja onnellisesta elämästä näyttää kiertyvän rajallisen planeetan rajattoman kulutuksen ympärille, voidaan mindfulness-filosofiassa ja käytännössä nähdä radikaalia potentiaalia. Tämä hyväksyväksi tai tietoiseksi läsnäoloksi käännetty ilmiö mahdollistaa sen, että ihminen voi oppia onnellisuutta pelkästä olemassaolosta (oletuksena tietysti perustarpeiden tyydytys, ks. Nussbaum 2007, 23-24).

Tämä kasvatusfilosofinen tutkimus koskee kontemplatiivisen pedagogiikan filosofiaa suhteessa konsumeristisen elämäntavan ongelmaan. Ensin taustoitan kontemplatiivisen pedagogiikan tarkastelua idän ja lännen jännitteen kautta ja määrittelen peruskäsitteitä, mistä pääsen laajentamaan yksiulotteista tapaa ymmärtää ihmistietoisuus. Sitten pohdin mielen assosiaatiovirtataipumusta sekä mielen assosiaatiotaipumuksen sivuuttamisen syitä suhteessa aikamme liberaaliin ihmiskuvaan. Mielen assosiaatiovirta voidaan havaita mieltä selkeyttävän fenomenologisen harjoituksen kautta, jota pidetään tässä myös kontemplatiivisen pedagogiikan perusharjoituksena. Tästä edetään tietoisuustaitojen esittelyyn suhteessa kriittisen tietoisuuteen sekä eksistenssianalyysiin ihmisen elämän epätyydyttävyyden syistä. Lopuksi tuon esiin sellaisen itsesuhteen mahdollisuuden, jossa ihminen oppii näkemään omien konsumerististen passioiden läpi ja suhtautumaan näihin sekä myös itseensä kevyemmin ja huumorintajuisemmin.

\section{KONTEMPLATIIVINEN PEDAGOGIIKKA IDÄN JA LÄNNEN VÄLISSÄ}

Lauri Rauhalan mukaan ihmistyöntekijöiden yleissivistykseen kuuluisi nykyisin ainakin alustava perehtyneisyys itämaisiin ihmisen kasvattamisen menetelmiin. Idässä on vuosituhansien ajan kehitetty erilaisia käyttökelpoisia filosofis-elämänkatsomuksellis-psykologis-uskonnollisia perinteitä ihmisen psyykkishenkisen kasvun sekä somaattisen hyvinvoinnin 
edistämiseksi. (Rauhala 1986, 11.) Kontemplatiivinen pedagogiikka onkin kasvatustieteen, -filosofian ja -käytännön suuntaus, joka ottaa Rauhalan ajatuksen vakavasti ja soveltaa paljolti idässä kehittyneitä meditatiivisia tietoisuustaitoharjoituksia (esim. hengitysten tarkkailu) erilaisiin yhteyksiin kotona, kouluissa, harrastuksissa ja työpaikoilla. Itämaisten harjoitteiden läntiset sovellukset edellyttävät kuitenkin aina maailmankuvien yhteensovittamista ja uudelleentulkintaa (Väänänen 2013).

Alan Wattsin (1977), Erich Frommin ja D. T. Suzukin kaltaisten tutkijoiden pohdinnat läntisen psykoanalyysin ja itäisen zen-buddhalaisuuden yhteyksistä (ks. Fromm \& Suzuki \& De Marino 1970) voidaankin nähdä tienraivaajina myös kontemplatiiviselle pedagogiikalle. Suomen tunnetuin mindfulnesin fenomenologian tutkija sekä myös käytännön soveltaja Timo Klemola $(2005,11)$ pyrkii "kulkemaan idän ja lännen välissä”. Samalla tiellä kulkee mindfulness-käsitteen yleiseen tietoisuuteen tuonut Jon Kabat-Zinn, joka on tunnettu meditaation käytännöllisistä sovelluksista esimerkiksi stressinhallinnassa. Tietoisuustaidot onkin suosittu lähestymistapa erityisesti psykologian ja terapian kentillä, joista myös kontemplatiivinen pedagogiikka on ottanut vaikutteita.

Vaikka länsimainen jako tieteen ja uskonnon välillä on itäisten meditaatio-traditioiden luokittelemisessa harhaanjohtava, voidaan mindfulnesin nähdä kumpuavan paljolti buddhalaisesta filosofiasta ja käytännöstä. Samantyyppisiä mielen harjoitteita sisältyy esimerkiksi islamin sufilaisuuteen, taolaisuuteen, hindulaisuuteen, juutalaiseen Kabbalaan, konfutselaisuuteen sekä kristillisyyteen, joten mistään uskonnollisista sitoumuksista ei voida puhua läntisessäkään mielessä (Walsh \& Shapiro 2006, 229; ks. Rauhala 1986, 15-16, 53). Buddhalaisissa teksteissä mindfulness, joka siis suomennetaan sanoilla "tietoisuustaito" ja "tietoinen läsnäolo", tunnetaan palin kielisellä termillä sati. Se viittaa muistamiseen ja tarkoittaa, että tietoisuustaitojaan harjoitteleva meditoija palauttaa huomionsa aina uudelleen valittuun kohteeseen. Fenomenologisen harjoituksen yhteydessä näemme harhailevan mielen kohteeseen palauttamisen tärkeyden. (Väänänen 2013.)
Kontemplatiivisen pedagogiikan filosofinen ja historiallinen kytkös juuri tällaisiin "itäisiin vapautuksen teihin" (Watts 1977) ei tarkoita idän mystiikkaa. Sen sijaan kyse on ensinnäkin siitä, että vastaavien harjoitteiden kehitys lännessä ei ole historiallisesti ollut niin systemaattista ja laaja-alaista kuin idässä (ks. Hadot 2010). Toiseksi myös länsimaisen kulttuurivirran pinnallisuutta voidaan pitää syynä idän viisausperinteisiin suuntautuneen kiinnostuksen lisääntymiseen (Rauhala 1986,9). Tämä pinnallisuus johtuu osin uskonnollisen maailmankuvan syrjäytymisestä (sekularisaatio) ja tieteellis-teknologisen maailmankuvan vallitsevuudesta, joista on siis seurannut arvotyhiötä ja vaikeuksia suunnistautua kohti ekologisesti viisaita ja eettisesti kestäviä arvopäämääriä.

Idän ja lännen välissä muotoutuvan kontemplatiivisen pedagogiikan "kontemplaatio" ymmärretään tässä monipuolisesti syvähenkisenä tai harrasmielisenä pohdiskelevuutena ja meditatiivisuutena. Kontemplaatio (lat. contemplatio) liittyi läntisessä kulttuuripiirissä keskiajalla uskonnollisten opinkappaleiden mietiskelyyn (lectio divina, ks. Kahane 2009, 56), ja latinan kielen contemplatio-sanaa on käytetty myös kreikan theoria-sanan käännöksenä. Molemmat latinan sanat viittaavat muun muassa jonkin katsomiseen 1) silmillä tai 2) mielellä eli huomion kiinnittämiseen johonkin. ${ }^{2}$ Läntinen rationalisoitunut ja teknistynyt kulttuuri painottaa ensimmäistä merkitystä, ulkoisen todellisuuden ( silmillä) observointia ja hallintaa. Kuitenkin kontemplatiivisen pedagogiikan painopiste on enemmän toisessa merkityksessä, ihmismielen sisäisten kokemuslaatujen kehittämisessä ja yksilön ja maailman välisen vieraantumisen voittamisesta (ks. Kahane 2009, 52-53; Bai \& Scutt 2009).

Puhuttaessa niin vaativista asioista kuin tietoisuustaidoista, joilla kultivoidaan ihmisen perenniaalisen viisauden komponentteja, kuten läsnäoloa, tyyneyttä ja hyväksyntää, voidaan helposti huomata myös kontemplatiivisen pedagogiikan määrittelyn vaikeus. Kysymykseen, mitä kontemplatiivinen pedagogiikka tai tietoisuustaidot ovat, ei voi saada tyydyttävää vastausta käsittein ilmaistuna (Grace 2010, 100). On eri sanoa, että mieli on tyyni ja keskittynyt kuin kokea tällainen mielentila (Koski 2002). Kontemplatiivinen pedagogiikka tähtää kuvattuihin mielentiloihin, 
joiden saavuttamista voidaan harjoitella vaikkapa työväenopiston jooga-kurssin tai liikunta- tai urheiluharrastuksen rentoutusharjoituksen, "kehoskannauksen" (ks. Kabat-Zinn 2005, 249-271), avulla. Kontemplatiivisen pedagogiikan perenniaalinen viisaus voikin avautua vaikkapa aikuiskasvattajalle kokemalla se itse käytännössä. Kokemuksia kontemplatiivisesta pedagogiikasta voi saada vaikkapa runon, tekstinpätkän, aforismin tai ajatuksen hiljaisesta mietiskelystä (ks. Kroll 2010; Grace 2010, 99-100) vain muutaman esimerkin tässä mainitakseni.

Vaikka kontemplatiivisessa pedagogiikassa suhtaudutaan avoimesti erilaisten traditioiden tietoisuustaitoharjoituksiin, on menetelmien ja filosofioiden oltava tutkittuja ja perusteltuja. Ideaalitilanteessa tietoisuustaitoharjoitukset yhdistyvät tieteelliseen tutkimukseen (Walsh \& Shapiro 2006), jonka kautta kontemplatiivinen pedagogiikka saa myös kasvatustieteelliset perustelunsa. Tukimusta meditaatiokäytäntöjen sovelluksista onkin tehty viime vuosikymmeninä runsaasti lupaavin tuloksin (esim. Walsh \& Shapiro 2006; Baer 2003), ja erilaiset meditatiiviset harrastukset kasvattavat suosiotaan erityisesti aikuisten parissa. Myös esimerkiksi työelämävalmennuksessa ja työhyvinvoinnin tukemisessa on nähty tilausta tietoisuustaidoille (ks. Juvakka 2011). Ennen tietoisuustaitojen ytimen, fenomenologisen harjoituksen, kuvaamista tarkastellaan vielä kontemplatiivisen pedagogiikan leviämismahdollisuuksiin liittyviä ihmiskuvallisia näkökohtia, joilla on ollut vaikutuksensa myös konsumerismin kehittymisessä.

\section{MIELEN LATTEA TASAMAA}

Länsimaissa vallitsevaa kulttuurista käsitystä ihmismielestä voidaan luonnehtia vielä Washin ja Shapiron (2006) mukaan yksiulotteiseksi (engl. monophasic), ja tällä on ollut suuri vaikutus esimerkiksi kasvatukseen sekä filosofiaan. Yksiulotteisen mielen käsite kuvaa sitä, kuinka länsimainen tarkastelu keskittyy lähinnä tavanomaiseen valvetietoisuuteen, jonka laatua ei ole kehitetty harjoituksen avulla. Tällaisesta valvetietoisuudesta poikkeaminen nähdään usein mielenterveysongelmana, jos siitä on yksilölle merkittävää käytännön haittaa. Meditatiivisten traditioiden käsitys ihmismielestä on taas moniulotteinen (engl. polyphasic). Moniulotteinen käsitys ottaa myös tavanomaisesta harjaantumattomasta valvetietoisuudesta poikkeavat tajunnantilat luontevaksi osaksi maailmankuvaansa ${ }^{3}$. Meditatiivisissa traditioissa mielen kykyjen harjoittelemisella nähdään mahdollisuuksia monenlaiseen tietoisuuden transformaatioon. (Walsh \& Shapiro 2006, 232-233; ks. KabatZinn 2006, 12.)

Läntisessä kulttuuripiirissä suhtaudutaan usein epäluuloisesti ja torjuvasti mielen moniulotteisuuteen paljolti siksi, ettemme ole vielä toipuneet siitä valtataistelusta, jota on käyty tieteen ja kirkon välillä erityisesti valistusfilosofian ja tieteen saadessa tuulta purjeisiinsa uusista läpimurroista. Tästä valtataistelusta seurasi nykypäivään asti lännessä vaikuttanut kahtiajako yhtäältä uskon, tunteen, uskonnon, mystisen, subjektiivisen ja transsendentin sekä toisaalta tiedon, järjen, objektiivisen ja immanentin välillä. Valtataistelun jäljiltä maailmamme jakautui jyrkästi tiedon ja uskon valtakuntiin, eivätkä ihmismielen moniulotteiset kokemukset täysin sovi tähän dualismiin. Tiede otti näin ihmismieleen varsin yksiulotteisen kannan ja alkoi väheksyä epätavallisia kokemuksia subjektiivisina ${ }^{4}$.

Meditaatioperinteissä esimerkiksi puhetta sellaisista transpersoonallisista ykseyskokemuksista, joissa yksilön tajunta laajenee myös ympäröivään maailmaan, pidetään eräänä harjoittelulla saavutettavana mahdollisuutena (Walsh \& Shapiro 2006, 232-233). Tällaisessa ykseyden kokemuksen harjoittelemisessa on nähty myös ympäristökasvatuksen mahdollisuuksia. Kokemus itsen ja luonnon yhteenkuuluvuudesta voi johtaa siihen, että luonto ja ympäristö koetaan itsen jatkeeksi. (Bai \& Scutt 2009, 99.) Näin luontoa voi kohdella kuten omia keuhkoja tai munuaisia (Wilberg 2009, 300-301) haluten ylläpitää niiden terveyttä kuluttamisen sijaan.

Kontemplatiivinen pedagogiikka ei kumpua antirationaalisuudesta tai uudesta magiasta (ks. von Wright 1987, 15-16) vaan pyrkii laajentamaan ajatuksiamme tietoisuudesta, tiedosta ja järjestä entistä moniulotteisemmaksi, sillä pelkästään rationaalinen ei ole välttämättä viisasta (Pulkki \& Saari, tulossa; von Wright 1987, 20-22). Kuiluja objektiivisen (tiedon) ja subjektiivisen (uskon) välillä pyritään täyttä- 
mään sikäli, kun se haittaa todellisuuden adekvaattia havainnointia (ks. Varela \& Shear 1999). Yleensä empiirisessä tieteessä tietoa ajatellaankin saavutettavan aistihavaintojen kautta tavallisessa mielentilassa (ks. Shear \& Jevning 1999, 190). Buddhalaisessa traditiossa mielen fenomenologinen tutkimus on ollut merkittävää reilut kaksi vuosituhatta. Sen enempää kuin Galileo Galilei olisi voinut saavuttaa tietoa tähtien liikkeistä kelvottomalla kaukoputkella, ei mielen sisäinen tutkimus voi luottaa kehnoihin "instrumentteihin" (Wallace 1999, 176). Kypsän kontemplatiivin tekemänä meditaatiota voidaan pitää yhdenlaisena tieteellisenä mielen tutkimuksen metodina (Malinen 2008). Itsetuntemus kuuluu kasvatuksen ydintavoitteisiin, eikä sekään palaudu vain rationaaliseen reflektioon, vaan edellyttää laajempaa kontemplaatiota.

Mielen moninaisuuden ymmärtämistä sekä itsetuntemuksen saavuttamisen mahdollisuuksia haittaava tieteen ja uskonnon vastakkainasettelu kehittyi siinä historiallisessa tilanteessa, jossa ancien régime murtui ja siirryttiin keskiaikaisista feodaalisista ja monarkistisista rakenteista demokraattisempiin ja egalitaarisempiin yhteiskuntiin. Vapautuminen uskonnollisesta ja maallisesta sorrosta, erityisesti synnynnäisistä etuoikeuksista ja eriarvoisuudesta, oli nykyiseenkin ajan henkeen vaikuttaneen liberalistisen filosofian päämäärä. Esimerkiksi Locken (1995, $\$ 4, \$ 6)$ mukaan luonnontilassa "meidät kaikki on varustettu samoilla kyvyillä”. Hobbes $(1985,183)$ näki luonnon tehneen ihmiset riittävän samanveroisiksi ruumiin ja mielen ominaisuuksiltaan.

Erilaiset "henkiset huippukokemukset" (ks. Wilberg 2009, 232-234) sopivat kitkaisesti siihen yhteiskuntafilosofiseen ja -käytännölliseen lähtökohtaan, että "meidät kaikki on varustettu samoilla kyvyillä". Empiirisesti voidaan havaita ongelmitta, että juoksumestari on ansainnut verrattomat kykynsä, mutta ihmistietoisuuden kehittymisen suhteen tämä havainto on epäselvempi. Tietoisuustaitomestarin tajunta onkin tavallista tietoisuutta laajempi, jolloin kapeammasta tajunnasta käsin tämä laajuus tai syvyys vaikuttaa käsittämättömältä (ks. Wilberg 2009; Hart 2004). Liberalismi on kyllä suvaitseva erilaisia ihmismieliä kohtaan, mutta tämä ei tarkoita, että liberaali subjektikaan täysin ymmärtäisi itseään laajempaa tajuntaa
- ilmiö, joka voidaan ymmärtää esimerkiksi Platonin luolavertauksen kautta. Juuri tällaisesta yhteismitattomuudesta on kysymys, kun todetaan, että kaikkien samojen kykyjen oletus ja henkiset huippukokemukset sopivat nihkeästi toisiinsa.

Edellinen kuvaus mielen moniulotteisuudesta transpersoonallisten ykseyskokemusten, henkisten huippukokemusten tai tietoisuustaitomestaruuden avulla ei tarkoita haikailua esimerkiksi shamanistisiin transsitiloihin. Mielen moniulotteisuuden ymmärtämisen kautta voidaan sen sijaan irtautua siitä mielen "latteasta tasamaasta" (Wilber 2009, 232-234), jossa koulumaailma operoi yksiulotteisesti lähinnä ulkokohtaisten faktojen, muistamisen, kognitioiden ja teknisluontoisten taitojen alueella. "Lattealla tasamaalla" ihmismieltä ei voi kehittää kokonaisvaltaisesti, kun juuri tätä myös konsumeristisen mentaliteetin transformaatio edellyttäisi. Erilaisiin tajunnantiloihin, kuten suhteellisuudentajuiseen kohtuullisuuteen, myötätuntoon ja "puhtaaseen tietoisuuteen" (ks. Shear \& Jevning 1999) sisältyy lukemattomia hyödyntämättömiä mahdollisuuksia. Seuraavassa käy ilmi, että esiin tuoduista mielen moniulotteisista potentiaaleista huolimatta kontemplatiivisessa pedagogiikassa on kysymys yleensä jostain varsin arkisesta.

\section{LIBERAALIN TAJUNNAN MIELIPUUHAT}

Avainhuomio kontemplatiivisessa pedagogiikassa on, että ihminen ei ole arkisessa tajunnassaan usein tietoisesti läsnä mielensä alituisessa puuhastelussa. Sen sijaan ihmisen toimintaa ohjaa sinne tänne poukkoileva mieli. (ks. Kabat-Zinn 2005, 230.) Käytämme aikaa haikailemalla mennyttä, unelmoimalla tulevaisuutta ja murehtimalla asioita, joihin emme voi vaikuttaa. Ajattelemme, toivomme, arvostelemme ja tunnemme. Olennaista on, että mielen assosiaatiovirta on heikosti hallittavissa, emmekä onnistu pitämään huomiotamme pitkään vapaasti valitussa kohteessa (Klemola 2002, 17; Kabat-Zinn 2005, 229). Mielen assosiaatiovirran hallitsemattomuus tulee ymmärtää tässä ihmismielen ja kontemplatiivisen pedagogiikan perusilmiönä, jolla on lukemattomia vaikutuksia. Miksi näin suurta asiaa ei ole otettu vielä riittävän vakavasti, kun ajatellaan tekstin alussa esitettyjä kon- 
sumerismin, niukkuuden ja ekologisen moraalisubjektiviteetin näköaloja?

Ensinnäkin ihminen on valistuksesta asti ymmärretty autonomiseksi subjektiksi, joka järkensä avulla vapautuu holhouksesta. Autonomia nähdään liberalismissa pikemminkin lähtökohtaoletuksena kuin kehityksen alaisena asiana (ks. Andersson \& Honneth 2005). Mielen assosiaatiovirran kuvitellaan olevan lähtökohtaisesti autonomisen subjektin hallinnassa, eikä sosiaalisten käytäntöjen, kuten kasvatuksen, vaikutusta tällaisen kehittymiseen oteta riittävästi huomioon. Toiseksi länsimaisiin kulttuureihin syvästi vaikuttanut taloustieteen homo economicus ihmiskuva pitää ihmistä taloudellista etuaan maksimoivana rationaalisena toimijana (ks. Marglin 2009). Tässäkin ongelmana on lähtökohtaoletus. Ihminen oletetaan "rationaaliseksi toimijaksi" ilman harjoitusta, sosialisaatiota ja kasvatusta.

Kolmanneksi liberaali filosofia painottaa yksityisomaisuutta tavalla, jossa ihmisen minä nähdään omaisuutena, jonka omaisuutta voidaan kartuttaa erilaisin (Malinen 2005) minätekniikoin. Tällaista ihmiskäsitystä voidaan kutsua Macphersonin (1962) tavoin omistusindividualismiksi. Tällainen omistusindividualisti painottaa vapautta muiden tahdosta, omaan etuun perustuvaa markkinakilpailua sekä oman minuutensa omistamista ja riippumattomuutta yhteiskunnasta (Macpherson 1962,263). Ihmisen omistussuhde omaan itseensä tarkoittaa esimerkiksi uusliberalisti Nozickilta löytyvää itseomistuksen ideaalia, joka liittyy tässä ajattelussa ylipäänsä omistusoikeuden rajoittamattomuuteen (Räsänen 2007), jonka ongelmallisuus konsumerismin ja luonnonvarojen niukkuuden kannalta on ilmeistä.

Yhteenvetona edellisestä ihmiskäsityksestä voidaan nähdä autonominen, omaneduntavoitteluun keskittyvä minä, joka samaistuu oman mielensä assosiaatiovirtaan, jota hän pitää omistuksenaan. Esimerkiksi uusliberalismissa pyritään maksimoimaan yksilön vapaudet omistaa ja kuluttaa. Tällaisesta ihmisestä tulee "atomistinen subjekti", joka ei koe olevansa mitään velkaa yhteiskunnalle (ks. Taylor 1985). Klassisessa liberalismissa ei ajateltu, että rationaalinen minä olisi erityisen tasapainoinen tai johdonmukainen halujensa suhteen (Sennett 2004, 111).
Näin liberaali kuluttajakansalaisuuden idea vaikuttaa ekologisesti kestämättömältä (Värri 2011,28).

Ihmismielen assosiaatiovirran hallitsemattomuus on siis perustavanlaatuinen huomio, sillä monet maailman ongelmat ovat heijastusta tästä hallitsemattomuudesta. Konsumerismi voidaan suhteuttaa Klemolan huomioon, jonka mukaan on pikemminkin niin, että minussa ajatellaan kuin minä ajattelen (Klemola 2002, 17). Minussa voi ajatella vuotuisen 500 miljardin markkinointikoneiston (Latousche 2010,32) rakentamat identiteettimallit, yleinen mielipide, muoti, sovinnaiskäsitykset ja niin edelleen. Autonomisena itsensä näkevä omistusindividualisti torjuu helposti tällaisen näkemyksen, sillä autonomiaidentiteetti suojelee oivallukselta, että minussa ajatellaan. Ihmismieli on usein "kuin voimakkaassa virrassa lipuva vene, jonka soutaja kuvittelee voivansa ohjata veneen liikettä mihin vain, mutta todellisuudessa hän on koko ajan virran vietävänä” (Klemola 2002, 17).

\section{FENOMENOLOGINEN HARJOITUS SELKEYTTÄÄ DISKURSIIVISTA MIELTÄ}

Lukija voi tässä kohtaa todentaa mielen assosiaatiovirrassaan lipuvan luonnon yksinkertaisella fenomenologisella harjoituksella, jota voi myös soveltaa vaikkapa oppitunnin, työpäivän tai kokouksen alkuun (käytännön ohjeita opettajalle esim. Schoeberlein 2009, luvut 1-3). Istu kymmenestä minuutista puoleen tuntiin paikallasi selkä suorassa ja keskitä huomiosi hengitykseen. Saman voi tehdä makuullaan. Kun mieleen nousee ajatuksia, tunteita, arvostelua, huolia ja muuta assosiaatiovirtaa, palaa aina hengityksen tarkkailuun ja anna assosiaatioiden mennä omia aikojaan mihinkään tarttumatta. Avuksi varsinkin aloittelijalle käytetään yleensä hengityksen laskemista yhdestä kymmeneen aina uudelleen alusta aloittaen. Näin mieli voidaan keskittää johonkin sen poukkoilun sijaan ja mielen assosiaatiovirta nähdään kuin etäämmältä ja oivalletaan sen luonne. (Esim. Klemola 2002, 17-18; Holmberg 2005, 86-90.)

Hengitysten laskemisharjoitus osoittaa, että huomion pitäminen hengityksiä representoivissa numeroissa on helpommin sanottu kuin tehty, kyseenalaistaen autonomisen itsehallinnan ja homo 
economicuksen ajatukset. Mieli jatkaa laskemisesta huolimatta yleensä tavanomaisissa puuhissaan, eikä vain hallitse itseään. Harjoittamalla tällaista tietoisuustaitoharjoitusta hiukan pidempään voi huomata, että mieleen kumpuavat mielikuvat, ajatukset, ihmetykset, arvostelut, toiveet ja huolet pikku hiljaa vetäytyvät. Niitä ei tule yhtä paljon ja suhde niihin muuttuu tarkkailevammaksi.

On helppo nähdä, kuinka diskursiivisen mielen hiljeneminen voi olla suureksi avuksi esimerkiksi kouluissa keskittymiskyvyn, työrauhan ja koulumenestyksen edistämisessä (ks. esim. Schoeberlein 2009; Greenland 2010; Willard 2010). Kontemplatiivisen pedagogiikan merkitys voidaan nähdä kuitenkin tätä syvällisempänä ja monipuolisempana. Kuvattu fenomenologinen harjoitus osoittaa yhden tien tietoisuustaitojen harjaantumiseen, mutta eriikäisille soveltuvia kontemplatiivisia menetelmiä on sadoittain (ks. Willard 2010), kuten visualisaatio, esineen keskittynyt tarkkailu, tietyn äänen keskittynyt kuuntelu, sanan pohtiminen, kuvaan keskittyminen ja vapaasti assosioiva kirjoittaminen (Repetti 2010, 7-8; Kahane 2009, 55). Aiheesta on tarjolla kirjallisuutta (esim. Grace 2011; Cohen \& Bai 2007; Schoeberlein 2009; Kroll 2010), ja fenomenologisen harjoituksen käytännön ymmärtämisen (ja kokemisen) kautta pääsee jo hyvin alkuun.

Olennaista kontemplatiivisissa harjoituksissa on ymmärtää mielen puuhasteleva luonne ja sen vaikutus ihmisen läsnäoloon ja kaikkeen toimintaan. Hengityksen tarkkailu on hyvä harjoitus, koska hengityksen tiedetään olevan avain kehon ja mielen välillä. Se korreloi mielen liikkeitä ja esimerkiksi kiivastuessa muuttuu raskaammaksi (Väänänen 2013) ja nopeammaksi. Fenomenologisen harjoituksen kautta huomaamme, kuinka aluksi jännittyneestä ja ikään kuin kahden janan välillä tempoilevasta hengityksestä tulee pehmeä, pyöreä ja rento. Tässä prosessissa myös mieli antaa periksi assosiaatiovirrastaan, rentoutuu, rauhoittuu ja kirkastuu.

\section{HYVÄKSYVÄ TIETOINEN LÄSNÄOLO JA KRIITTINEN TIETOISUUS}

Tietoisuustaidoilla (mindfulness) tarkoitetaan siis mielen kykyä hyväksyvään, läsnä olevaan tietoisuuteen sekä tietoisuuteen mielen tuottamista kokemuksista ja tulkinnoista (Lehto \& Tolmunen 2008, 41). Tietoisuustaidoissa, josta fenomenologinen harjoitus on esimerkki, keskitytään nykyhetkeen pyrkimättä muuttamaan sitä. Tietoisuustaitojen harjoitteissa huomio palautetaan yhä uudelleen nykyhetkeen, kun mieli lähtee puuhastelemaan omilla kiertoradoillaan. (Juvakka 2011, 45-46; Holmberg 2005, 77-78.) Olennaista on tulla tietoiseksi ajatuksistaan ja aistimuksistaan ilman pyrkimystä ja arviointia. Tietoiseksi tulemalla ihminen voi siirtyä automaattiohjauksesta pois. (Holmberg 2005, 77-78.)

Eivätkö hyväksyntää painottavat tietoisuustaidot ole ristiriidassa yhteiskunnallisen muutosagenttiuden ja kriittisen tietoisuuden kanssa? Eikö kaiken hyväksyminen tarkoita muutoksen tavoittelusta luopumista ja kaiken kritiikitöntä hyväksymistä? Tällaisesta ei ole kysymys. Hyväksyntä ei tarkoita kaiken aktiivisen ja päämäärätietoisen toiminnan lopettamista, vaan uudenlaista suhdetta tekemiseen (Juvakka 2011, 49-50). Kysymys ei ole akrasiasta, eli tahdonheikkoudesta, luovuttamisesta tai epätietoisuudesta, vaan todellisuuden hyväksynnästä. Jos yksilö ei pysty hyväksymään todellisuutta, kuten vaikkapa kärsimättömän idealistin tapauksessa, voi äly ja kirjanoppineisuus olla turhaa ja todellisuuden epäkohtien tiedostaminen voi johtaa turhautumiseen ja epätoivoon (ks. de Mello 2010, 133).

Hyväksyntä, arvostelemattomuus ja kärsivällisyys ovat keskeisiä tietoisuustaitoja (Kabat-Zinn 2005, 118-127), joita tarvitaan myös yhteiskunnallisessa muutostyössä. Lisäksi ihmisen itsensä muuttaminen on jo itsessään maailman muuttamista, sillä minä on osa maailmaa (ks. Kabat-Zinn 2010, 33). Monien kasvatusfilosofien peräänkuuluttama kriittinen järjenkäyttö ja medialukutaito demokratian toteutumiseksi edellyttävät seurakseen tietoisuustaitoja, kuten rauhallista mieltä, empatiakykyä, käytännöntajua, hyväksyntää sekä yhteistyökykyä. Tietoisuustaitojen aloittelija voi jäädä kiinni ajatusten, uskomusten, odotusten, toiveiden ja pelkojen verkkoon. Kun emme tiedosta meitä hallitsevia motiiveita, on tällä vaikutusta kaikkiin päätöksiimme (Kabat-Zinn 2005, 108).

On helppo huomata myös tällaisen tiedostavuuden puutteen moraalinen ongelmallisuus. Usein 
kyse on siitä, että arjen tilanteita ei havaita moraalisesti relevanteiksi, koska ihminen on niin kiinni omissa mielen puuhissaan (Blum 1991). Havainnoidaksemme mielemme hienovaraisimpia mekanismeja meidän terävöitettävä kykyämme itsetarkkailuun (Ricard 2010, 22). Kriittisen tietoisuuden ja tietoisen läsnäolon kehittymiseksi meidän on omaksuttava taito tyhjentää mielen puuhastelu ja mentävä mielen epädiskursiiviseen perustaan, joka on kaiken toiminnan taustalla. Näin mieli voi avautua tämän hetken havainnointiin, jossa ei ole kyse "objektiivisesta" ulkomaailman havainnoinnista tai "subjektiivisesta" mielen havainnoinnista, vaan ylipäätään molemmista.

Läsnäolemattomuus, laadultaan vääristynyt läsnäolevuus tai "mindlessness" (esim. Schoeberlein 2009, 7) ovat mahdollistaneet myös monenlaisten laajamittaisten julmuuksien toimeenpanemisen esimerkiksi 1900-luvun sodissa ja kansanmurhissa. Ihmistä kohdellaan pelkkänä välineenä, kun hänen ihmisyyttään ei nähdä tarkasti. Läsnäololla tässä ja nyt, myös toisen iloissa ja kärsimyksissä, on myötätuntoa lisäävää vaikutusta, sillä myötä tunteminen edellyttää läsnäoloa. Toisten kokemuksia voi myötätuntea paremmin, kun oman mielen aallot eivät peitä niitä alleen. Myötätunnon kehittyminen mainitaan usein kontemplatiivisen pedagogiikan ja meditaation hyödyksi.

Huomasimme edellä, että tietoisuustaitojen harjoituksen kautta tajunnan assosiaatiovirta hiljalleen vetäytyy ja hiljenee, jolloin voidaan saavuttaa yhä enemmän vanhoista rasitteista vapaata tilaa, jossa inhimillisen kokemisen uudelleenorganisoitumisesta tulee uudella tavalla mahdollista (Rauhala 1986, 57). Pysäyttämällä tietoisuudessa toimivan ajatusten, teorioiden, faktojen, uskomusten, asenteiden ja tunteiden vyöryn ihminen voi saavuttaa harjoituksella "puhtaan tietoisuuden" (Shear \& Jevning 1999), eli tietoisuuden itsessään, puhtaana, äänettömänä ja ilman fenomenaalisia objekteja. Entiset perustelemattomat kiintymykset tiettyihin ajattelutapoihin, elämäntapoihin ja uskomuksiin voivat avautua muutokselle. Kriittinen, avara sekä joustava tietoisuus edellyttääkin aivan ensimmäiseksi tietoisuutta oman assosiaatiovirran laaduista, alkuperistä ja motivaatioista. Tällainen todellisuuteen juurtunut läsnä oleva tietoisuus, joka ei toimi autopilotilla, voi haastaa konsumeristisesta uutuudenviehätyksestä elävän mentaliteetin sortumatta menneisyyden romantisointiin tai todellisuudesta vieraantuneeseen tulevaisuuden utopisointiin.

\section{ONNELLISUUS, KONSUMERISMI JA ELÄMÄN EPÄTYYDYTTÄVYYS}

Totunnaisista reagointi-, ajattelu-, tuntemis- ja asennoitumistavoista muodostuvat ehkä suurimmat esteet omalle onnellisuudellemme vauraissa teollisuusmaissa. Kasvatuksen tärkeimpänä tehtävänä voidaankin pitää antiikin filosofien hengessä hyvän ja onnellisen elämän mahdollistamista. Nykyaikaisessa ajan hengessä hyvää elämää lähestytään tunnetusti kuluttamisen kautta. Aikamme tarveliberalismin mukaan yksilöllä on vapaus ja oikeus haluta, tarvita sekä kuluttaa (Turunen 1997, 85-86). Jo Tocqueville (1805-1859) huomasi, että elintason ja tasa-arvon kehitys synnyttää ihmisiä, jotka tottuvat pitämään itseään erillisinä yksilöinä, jotka eivät ole kenellekään velkaa mitään, vaan sen sijaan sulkeutuvat "lopulta kokonaan omaan yksinäiseen sydämeensä" (Tocqueville 2006, 496). Tässä yksinäisessä sydämessä yksilö yrittää täyttää elämänsä eksistentiaalista tyhjiötä ja saavuttaa onnellisuutta konsumerismin kautta.

Ekologisen moraalisubjektiviteetin haasteeseen voidaan tuskin vastata pysyttäytymällä tällaisen atomistisen, omistusindividualistisen sekä tarveliberalistisen ihmiskäsityksen varassa, jossa yksilö rakentaa minuuttaan kulutushyödykkeiden omistamisen kautta. Ongelma on siinä, että tällainen yksilö ei osaa kunnolla erottaa mielensä automaattisluontoiseen assosiaatiovirtaan perustuvia haluja perustarpeista (Pulkki 2010; ks. Marglin 2009, 207-212). Omistusindividualisti samaistuu mielensä assosiaatiovirtaan ja haluihin, eikä näe konsumerismin epätyydyttävyyttä. Voimmekin Värrin $(2011,34,36)$ tavoin nähdä nykyaikaisen kasvatuksen ekologisena sivistysprojektina, jonka eräs keskeinen puoli on mielihyvän kultivointi sellaiseksi, ettei se ole ristiriidassa ympäristön kantokyvyn kanssa. Kontemplatiivisen pedagogiikan ja konsumerismin kannalta on tärkeää huomata, että jo Aristoteleen $(2005,1099$ b) mukaan onnellisuutta voidaan oppia ja harjoitella. Tarveliberalistisen yksi- 
löllisyyden ja elämäntavan ydinongelma yhdistettynä autonomian ihanteeseen sekä omistusindividualismiin, on siinä, että se ohjaa ihmisen eräänlaiseen tyytymättömyyden ja onnettomuuden kehään. Tällainen ajattelutapa nähdään ainakin stoalaisuudessa ja buddhalaisuudessa (dukkha). Stoalais-filosofi Epiktetos ilmaisee asian toteamalla, että "jos haluat jotakin, joka ei ole meidän vallassamme, joudut välttämättä onnettomaksi” (Epiktetos 2005, II). Degrowth-ajattelun isä Serge Latousche (2010, 23) on todennut kiinnostavasti mainonnasta, että "se luo aina vain lisää tyytymättömyyttä ja toteutumattomien halujen jännitettä”.

Aristoteleen $(2005,1104 b)$ mukaan oikea kasvatus on sitä, että pitäisi lapsesta asti oppia kokemaan kärsimystä ja mielihyvää oikein. Ihminen voi oppia arvostavuutta ja kiitollisuutta esimerkiksi hyvin palvellutta kestävää polkupyörää kohtaan ja huoltaa sekä vaalia sitä sen sijaan, että havittelisi aina uutta. Suurisieluinen ei Aristoteleen (ibid, 1124b) mukaan "tavoittele sitä, minkä perässä kaikki muut juoksevat". Fenomenologisella tai "filosofisella harjoituksella" (ks. Kortelainen, tulossa) pikkumaista konsumerismia, jossa aitoa onnellisuutta ei eroteta harhoista, voidaan oppia.

Kun liberalismissa minä on ihmisen omaisuutta, jota ihmisen tulee varjella, se on edellä esitetyn tyytymättömyyden "eksistenssianalyysin" (ks. Klemola 2005, 244) näkökulmassa varsinainen elämämme epätyydyttävyyden aiheuttaja. Koko konsumeristinen markkinataloussivilisaatio näyttäisi kärsivän kuvatusta tyytymättömyyden oravanpyörästä. Tämä oravanpyörä perustuu kuvitelmaan, että minä olisi jotain kiinteätä ja muuttumatonta omistusta, josta tulisi pitää tiukasti kiinni. Kuitenkaan minällä ei ole poststrukturalistissa, narratiivisissa ja buddhalaisessa lähestymistavassa pysyvää ja riippumatonta luontoa (Malinen 2007; 2005). Kaikki ilmiöt ovat väliaikaisia ja katoavaisia ja takertuminen pysyvyyden ajatukseen tuottaa vain pettymyksiä. Ihmisen minä on siinä mielessä "tyhjä", että sillä ei ole erillistä ja riippumatonta todellisuutta. Kun konteksti muuttuu, myös "minä" muuttuu, ja minän "todellisuus" todellistuukin vuorovaikutuksessa toisten ihmisten kanssa. Minä ei ole pysyvää "omaisuutta", vaan muuttuvaa, kehittyvää ja prosessiluonteista, tarinoista koostuvaa. (Malinen 2005; 2007.)

\section{KOHTI KEVEÄMPÄÄ ITSESUHDETTA}

Kaiken väliaikaisuus, minuuden muuttuvuus sekä minuuden perustuminen kulttuurisiin tarinoihin, joita kerromme itsellemme, on myös läpivalaistavissa fenomenologisen harjoituksen kautta. Mielemme assosiaatiovirrassa petymme, yllätymme, toivomme, odotamme, otaksumme, haluamme ja niin edelleen. Mielemme järkkyy, kun oletuksemme, toiveemme ja halumme eivät toteudu. Elämän epätyydyttävyyden pohjavirettä, joka ajaa ihmistä konsumerismiin, ei usein edes tunnisteta sen enempää kuin kala tunnistaa veden, jossa se elää, vedeksi. Tietoisuustaitojen ja kontemplatiivisen pedagogiikan hengitysharjoituksen kautta voimme tulla tietoiseksi elämän epätyydyttävyyden lähteistä. Mielentilat ovat tällöin kuin sipulinrenkaita, joita kuoritaan pois samalla oppien olemaan samaistumatta näihin (Väänänen 2013). Hyväksyvässä ja tietoisessa läsnäolossa onkin kysymys juuri samaistumattomuudesta ja takertumattomuudesta, sillä näihin perustuu paljolti juuri ihmisen eksistentiaalinen tyytymättömyys.

Eräs tärkeä teema tietoisuustaidoissa onkin useimpien tunnekokemusten väliaikaisuus ja ohimenevyys (Juvakka 2011, 45-46). Kun ihminen näkee, että niiden toteutumattomien pyyteiden, halujen ja tarpeiden todellisuus ei ollutkaan absoluuttista, vaan oikeammin illuusiota, hän voi olla onnellinen myös silloin, kun vähemmän tärkeät konsumeristiset passiot eivät toteudu. Merkittävin hyöty tietoisuustaitojen kehityksestä on Juvakan (2011,49-50) mukaan siinä, että ne mahdollistavat uuden suhteen luomisen omaan elämäntilanteeseen ja kärsimykseen. Kyse on siis siitä, että ajatusten luonne ymmärretään vain ajatuksina (Kabat-Zinn 2010, 101), eikä niinkään pakottavana "todellisuutena". Onnellisuuden saavuttaminen edellyttää asioiden todellisen luonnon ymmärtämisen ilman halujen, tunteiden tms. vääristävää vaikutusta (Klemola 2005, 243-244).

Kysyttäessä, mikä ihmisessä on se, joka on onnellinen, kärsii, haluaa, pelkää, huolehtii, kuluttaa ja on tyytymätön, voidaan vastauksena nähdä ego. Ihmisen ego tarkoittaa tässä ihmisen tietoisuutta omasta 
minästään. Itsetietoisuuden ansiosta ihminen voi kokea olevansa muusta maailmasta irrallinen atomistinen subjekti, jolla on mieltymyksiä, haluja, ajatuksia, toiveita ja uskomuksia. Minän tai egon jalostamattomat halut, toiveet, uskomukset ja ajatukset eivät kuitenkaan vastaa sitä, mitä ulkomaailma voi minulle antaa. Näin minä ja maailma asettuvat ikään kuin vastakkain. Minä käpertyy helposti itseensä ja elää tässä tilassa sitä itse tiedostamatta. (Ks. Koski 2002, 98; Ricard 2010, 107.) Liberaali omistava yksilö kuvittelee olevansa ("negatiivisesti") vapaa, kun sitä ei rajoita ulkoisesti mikään. Kuitenkin tällainen mieli toimii totunnaisten reaktioiden automaattiohjauksessa (ks. Kabat-Zinn 2005; Cohen \& Bai 2007).

Eräs syy ihmisen tyytymättömyyteen on juuri siinä, että hän samaistuu tarinoihin siitä, mitä hän on tai mitä hän tarvitsee ollakseen onnellinen. Onnellisuus edellyttää hyppäämistä tyytymättömyyden kehästä pois, kun se on ensin sellaiseksi tunnistettu. Tunnistaminen tapahtuu vähittäin esimerkiksi fenomenologisen harjoituksen kautta, jossa yksilö laskee hengityksiään. Näin ihminen voi ymmärtää häntä hallitsevan assosiaatiovirran etäämmältä jäämättä aina sen vangiksi. Zen-filosofiassa tunnetaan kielikuva lammesta, jonka veden humus sekoittuu myrskyllä ja tekee siitä sameaa. Hyväksyvää läsnäoloa opettava hengityksen tarkkailu tarkoittaa tässä suhteessa sitä, että lammen annetaan olla sellaisenaan, jolloin humus painuu itsekseen pohjalle ja vesi kirkastuu. Kirkkaassa mielentilassa ihminen usein oivaltaa, että kaikki onkin hyvin juuri nyt!

Tällainen harjoitus kultivoi taitoa suhtautua itseensä entistä keveämmin, ilman vääränlaista itsetärkeyttä, vähemmän takertuvasti (Malinen 2007; 2008). Kun ihminen ei suhtaudu omistushaluisella itsetärkeydellä ja mahtipontisuudella itseensä, hänen ei tarvitse keskittyä elämässään siihen, että hänen ansioluettelo, vaatteet, puhe, vartalo, talo, auto ja niin edelleen täyttävät vallitsevat esteettiset ihanteet. Näiden merkitys ei taianomaisesti poistu, mutta mielestä voi tulla joustavampi (ks. Willard 2010, 64, 81) ja ihminen voi juurtua eksistentiaalisesti todellisuuteen "varsinaisen minuutensa" kautta. Ajatuksia ei oteta enää niin vakavasti, vaan niiden luonne nähdään assosiaatiovirtana, johon voidaan ottaa havain- noiva asenne. Mielen puuhastelun tunnistamisen kautta myös negatiivisten ajatusten kehät voidaan katkaista jo alkuvaiheessa. (Ks. Juvakka 2011, 47-48; Baer 2003.)

Yllä kuvatussa kontemplatiivisen pedagogiikan harjoitteessa tunteita ja ajatuksia ei pyritä muuttamaan ajattelemalla niitä vielä lisää, vaan mielen sisältöjen arvostelematon havainnointi hioo mieltä kuin itsestään tavoilla, jotka edistävät ymmärrystä, myötätuntoa ja eheyttä (Kabat-Zinn 2010, 101). Mitä enemmän yritämme välttää epämiellyttäviä tunteita ja ajatuksia, sitä kauaskestoisempia ja voimakkaampia niistä tulee. Yritykset välttää ja paeta epämiellyttäviä tunteita ja ajatuksia johtaa useimmiten näiden lisääntymiseen ${ }^{5}$. (Holmberg 2005, 84.) Hyväksymällä ajatukset ja tunteet lopetamme takertumisen niihin, jolloin ne näyttäytyvät vain tavallisena assosiaatiovirtana.

\section{LOPUKSI}

Tämän tutkimuksen nojalla kontemplatiivinen pedagogiikka voidaan nähdä kasvatustieteen ja -filosofian suuntauksena, joka operoi tietoisuustaitojen filosofian ja metodologian parissa ja soveltaa niitä eri konteksteihin lukemattomilla tavoilla, joista tässä tuotiin esiin lähinnä fenomenologinen hengitysten laskemisharjoitus. Kontemplatiivinen pedagogiikka jatkaa perenniaalisen filosofian perinnettä kiinnostuksessaan hyvään elämään, onnellisuuteen, viisauteen, etiikkaan ja yhteiskuntaan. Kyse ei ole atomistisen subjektin itseensä käpertymisestä, mielen kehittämisestä kilpailusuhteessa toisiin kilpailijoihin (Saari \& Pulkki 2012). Tällaisessa viitekehyksessä on luontevaa tarkastella yksilön tajunnan ja konsumerismin yhteyksiä, sillä nämä kietoutuvat toisiinsa yhtä perustavalla tavalla kuin yksilö ja yhteiskunta yleisesti.

Lukuisia tutkimuksen ulkopuolelle jääneitä yhteiskunnallisia muutoksia tarvitaan, jotta ihmiselämä maapallolla olisi mahdollista myös pitkällä aikavälillä. Tässä näkökulma rajattiin kontemplatiivisen pedagogiikan ja filosofian mahdollisuuksiin hillitä tarveliberalistisen omistavan subjektin konsumeristisia mielihaluja. Taitava tietoisuus osaa olla onnellinen kohtuullisen vähälläkin kulutuksella, jos perustarpeet on tyydytetty - miten nämä sitten yhteisössä määritelläänkin. Siinä, että ihminen saa viattoman onnel- 
lisuuden kokemuksia vain olemisesta ja heittää pois samaistumisensa harhaluuloihin (ks. de Mello 2010, 69) vaikkapa kuluttamisen tuomasta onnesta, on jotain ekologisesti radikaalia.

Olennaista on lopettaa kuluttajakansalaisuuteen samaistuminen. Thorstein Veblenin (2002) mukaan "kerskakulutuksessa" on kysymys muun muassa siitä, että yksilö haluaa täyttää yleiset kunniallisuuden mittapuut. Juurtuessaan todellisuuteen omakohtaisella tavalla kontemplatiivisten harjoitusten kautta yksilö voi kasvaa "suurisieluiseksi" (Aristoteles 2005, $1124 b$ ), joka ei "tavoittele sitä, minkä perässä kaikki muut juoksevat". Suurisieluinen ihminen voi suhtautua itseensä sekä omaan konventionaaliseen kunnial- lisuuteensa keveästi ja huumorilla ja näkee sellaisten kunniallisen elämän kriteerien läpi, jotka ovat ristiriidassa luonnon kantokyvyn kanssa. Kunniallisuuden mittapuita ja hyväksyttäviä ja riittäviä perustarpeita voidaan koko yhteisön voimin määrittää uusiksi (Latousche 2010,65).

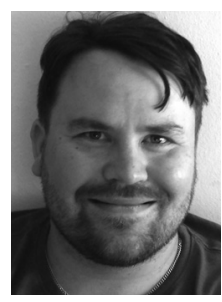

Jani Pulkki

KM, LuK, tutkija

Kasvatustieteiden yksikkö

Tampereen yliopisto

\section{LÄHTEET}

Anderson, J. \& Honneth, A. 2005. Autonomy, Vulnerability, Recognition, and Justice. Teoksessa John Christman and Joel Anderson (toim.) Autonomy and the Challenges to Liberalism: NewEssays. New York: Cambridge University Press, 127- 49 .

Aristoteles 2005. Nikomakhoksen etiikka. Suom. S. Knuuttila. Helsinki: Gaudeamus.

Baer, R.A. 2003. Mindfulness Training as a Clinical Intervention: A Conceptual and EmpiricalRewiev. Clinical psychology: science and practice 10, 125-143.

Bai, H. \& Scutt, G. 2009. Touching the Earth with the Heart of Enlightened Mind: The Buddhist Practice of Mindfulness for Environmental Education. Canadian Journal of Environmental Education 14, 92-106.

Bai, H. \& Scott, C. \& Donald, B. 2009. Contemplative Pedagogy and Revitalization of Teacher Education. Alberta Journal of Educational Research 55 (3). 319-334.

Bardy, M. 2011. Epilogi II. Maailmankuva ja ekososiaalinen järjestys. Teoksessa E. Palola \& V. Karjalainen (toim.) Sosiaalipolitiikka - Hukassa vai uuden jäljillä? Helsinki: Terveyden ja hyvinvoinnin laitos, 333-347 http://www.thl.fi/thl-client/ pdfs/970d363e-9edf-4b54-a76e-446b81ed34b5. Luettu 27.11.2012.

Blum, L. 1991. Moral Perception and Particularity. Ethics 101 (4), 701-725.

Cohen, A. \& Bai, H. 2007. Dao and Zen of Teaching: Classroom as Enlightened Field. Educational Insights 11 (3) http://www.ccfi.educ.ubc.ca/ publication/insights/v11n03/articles/bai/bai.html. Luettu 27.11.2012.
Epiktetos 2005. Ojennusnuora. The Project Gutenberg EBook. Suom. K. Jaakkola. http://www.gutenberg. org/cache/epub/16620/pg16620.html. Luettu 27.11.2012.

Fromm, E. \& Suzuki, D. T. \& De Marino, R. 1970. Zen Buddhism and Psychoanalysis. New York: Harper \& Row.

Grace, F. 2011. Learning as Path, Not a Goal: Contemplative Pedagogy - Its Principles and Practices. Teaching Theology and Religion. 14 (2), 99-124.

Greenland, S. K. 2010. The Mindful Child. How to Help Your Kid Manage Stress and Become Happier, Kinder and more Compassionate. New York: Free Press.

Hadot, P. 2010. Mitä on Antiikin Filosofia? Suom. T. Kilpeläinen. Tampere: Niin \& Näin.

Hart, T. 2004. Opening the Contemplative Mind in Classroom. Journal of Transformative Education 2 (1), 28-46.

Hobbes, T. 1985. Leviathan. London: Penguin Books.

Holmberg, N. 2005. Zen, Mindfulness ja vaeltava mieli. Kognitiivisen psykoterapian verkkolehti 2 (2), 72-93 http://www.kognitiivinenpsykoterapia.fi/ verkkolehti/2005/ktzen.pdf Luettu 27.11.2012.

Homer-Dixon, T. 1999. Enviroment, Scarcity and Violence. Princeton and Oxford: Princeton university press.

Jung, C. G. 1991. Foreword. In Suzuki, D. T. 1991 (1969) An Introduction to Zen Buddhism. (ed. Humphreys, C.) London: Rider books, 9-29.

Juvakka, T. 2011. Tietoisuustaitojen oppiminen työhyvinvoinnin tueksi. Kognitiivinen Psykoterapia 8 (1), 45-59. 
Kabatt-Zinn, J. 2005. Full Catastrophe Living. Using the Wisdom of Your Body and Mind to Face Stress, Pain, and Illness. New York: Bantam Dell.

Kabat-Zinn, J. 2006. Olet jo perillä - Tietoisen läsnäolon taito. Suom. T. Turpeinen. Helsinki: Basam Books.

Kabat-Zinn, J. 2010. Tietoinen läsnäolo maailmassa. Suom. S. Takkala. Helsinki: Basam Books.

Kahane, D. 2009. Learning about obligation, compassion, and global justice: The place of contemplative pedagogy. New Directions for Teaching and Learning. 118, 49-60.

Klemola, T. 2002. Filosofian harjoitus - harjoituksen filosofia. Niin \& Näin 3, 13-20.

Klemola, T. 2005. Taidon filosofia - filosofian taito. Tampere University Press.

Kortelainen, I. (tulossa). Huomion suuntaaminen filosofisena harjoituksena. Teoksessa Saari, A. \& Kortelainen, I. \& Väänänen, M. (toim.) Tietetoisuustaidot ja tieteet. Ilmestymässä 2014. kustantaja avoin.

Koski, T. 2002. D. T. Suzuki ja zen - kuuta osoittavat sormet. Niin \& Näin 2, 94-99.

Kroll, K. 2010. Contemplative Practice in Clasroom. New Directions for Community Colleges 151, 111-113.

Latouche, S. 2010. Jäähyväiset kasvulle. Suom. M. Ollila. Helsinki: Like.

Lehto, S. ja Tolmunen, T. 2008. Onko tietoisuustaidon harjoittelulla terveysvaikutuksia? Suomen Lääkärilehti 1-2, 41-45.

Locke, J. 1995 Tutkielma hallitusvallasta. Tutkimus poliittisen vallan oikeasta alkuperästä, laajuudesta ja tarkoituksesta. Suom. M. Yrjönsuuri. Helsinki: Gaudeamus.

Macpherson, C. B. 1962. The Political Theory of Possessive Individualism: From Hobbes to Locke. Oxford: Clarendon Press.

Malinen, T. 2005. Narratiivisia vinjettejä Osa 2: Identiteettipäätelmien purkamisesta. Ratkes 2.

Malinen, T. 2007. Mikä helpotus: minua ei ole! - eiminästä ja tyhjyydestä psykoterapiassa. Ratkes 1.

Malinen, T. 2008. Buddha, Wittgenstein ja postmodernit terapiat. Ratkes 3.

Marglin, S. 2009. Dismal science. How thinking like an economist undermines society. New York:Oxford university press.

de Mello, A. 2010. Havahtuminen. Suom. V. Rissanen. Helsinki: Like.

Nussbaum, M. 2007. Human Rights and Human Capabilities. Harvard Human Rights Journal 20, $21-24$.

Pulkki, J. 2010. Voitonhimon ongelma. Tiedepolitiikka 4. $39-52$.
Pulkki, J. \& Saari, A. (tulossa). Voiko hiljaisuudesta oppia? Kriittisiä näkökulmia kontemplatiiviseen pedagogiikkaan. Teoksessa Saari, A. \& Kortelainen, I. \& Väänänen, M. (toim.) Tietetoisuustaidot ja tieteet. Ilmestymässä 2014, kustantaja avoin.

Rauhala, L. 1986. Meditaatio. Helsinki: Otava.

Repetti, R. 2010. The Case for a Contemplative Philosophy of Education. New Directions for Community Colleges 151, 5-15.

Ricard, M. 2010. Meditoinnin Taito. Suom. L. Siitonen. Helsinki: Basam Books.

Räsänen, P. 2007. Uusliberalismi ja lupaus vapaudesta. Niin \& Näin 4, 99-107.

Saari, A. \& Pulkki, J. 2012. "Just a Swinging Door" - Examining the Egocentric Misconception of Meditation. Paideiusis 20 (2), 15-24 http://journals. sfu.ca/paideusis/index.php/paideusis/article/ view/276/186 Luettu 27.11.2012.

Schoeberlein, D. 2009. Mindful Teaching and Teaching Mindfulness. A Guide For Anyone Who Teaches Anything. Boston: Wisdom Publications.

Sennett, R. 2004. Kunnioitus eriarvoisuuden maailmassa. Suom. K. Koskinen. Tampere: Vastapaino.

Shear, J. \& Jevning, R. 1999. Pure Consciousness: Scientific Exploration of Meditation Techniques. In Varela, F. \& Shear, J. (eds.) The View Within. First Person Approaches to the Study of Consciousness. Exeter: Imprint, 189-209.

Taylor, C. 1985. Philosophy and the Human Sciences. Philosophical Papers 2. Cambridge: Cambridge University Press.

Turunen, K. 1997. Halut, arvot ja valta. Jyväskylä: Atena. de Tocqueville, A. 2006. Demokratia Amerikassa. Suom. S. Jansson. Helsinki: Gaudeamus.

Vainio, N. 2001. Liikkuva filosofi - keskustelu Tapio Kosken kanssa. Niin \& Näin 1, 33-35.

Varela, F. \& Shear, J. 1999. First-person Methodologies: What, Why, How? In Varela, F. \& Shear, J. (eds.) The View Within. First Person Approaches to the Study of Consciousness. Exeter: Imprint, 1-14.

Veblen, T. 2002. Joutilas luokka. Suom. T. Arppe \& S. Riukulehto. Helsinki: Art House.

von Wright, G. H. 1987. Tiede ja ihmisjärki. Suunnistusyritys. Suom. A. Leikola. Helsinki: Otava.

von Wright, G. H. 1992. Minervan pöllö. Esseitä vuosilta 1987-1991. Helsinki: Otava.

Värri, V.-M. 2011. Vastuu ihmisen mittana. Kasvatusteoreettisia ja filosofisia näköaloja ekologiselle sivistysprojektille. Tiedepolitiikka 4. 27-38.

Värri, V.-M. \& Saari, A. 2012. Ontology of Flesh and Its Implications to Education. Esitelmä konfrenssissa Practices, Bodies, and Things in Pedagogy. International symposium at Pädägogische Hochscule Heidelberg 28-29.9.2012. 
Väänänen, M. (tulossa). Vipassana ja tietoinen läsnäolo. Teoksessa Saari, A. \& Kortelainen, I. \& Väänänen, M. (toim.) Tietetoisuustaidot ja tieteet. Ilmestymässä 2014, kustantaja avoin.

Väänänen, M. \& Kortelainen, I. \& Saari, A. (tulossa). Johdanto. Teoksessa Saari, A. \& Kortelainen, I. \& Väänänen, M. (toim.) Tietetoisuustaidot ja tieteet. Ilmestymässä 2014, kustantaja avoin.

Wallace, A. B. 1999. The Buddhist Tradition of Samatha: Methods for Refining and Examining Consciousness. In Varela, F. \& Shear, J. (eds.) The View Within. First Person Approaches to the Study of Consciousness. Exeter: Imprint, 175-187.

Walsh, R. \& Shapiro, S.L. 2006. The Meeting of Meditative Disciplines and Western Psychology: A Mutually Enriching Dialogue. American Psychologist 61 (3), 227-239.

Watts, A. 1977. Psykoterapiaa idästä ja lännestä. Suom. M. Rutanen. Helsinki: Otava.

Wilberg, K. 2009. Kaiken lyhyt historia. Suom. J. P. Jakonen. Helsinki: Basam books.
VIITTEET

1 Käsitehistoria (Väänänen \& Kortelainen \& Saari tulossal tosin osoittaa, ettei aivan synonyymeistä ei ole kysymys.

2 Käsitteiden etymologia tarkastettu esimerkiksi sivulta http://www.etymonline.com

3 Historiallisesti rakentunut kategoriaero normaalin ja paranormaalin tai luonnollisen ja yliluonnollisen välillä on epäadekvaatti tarkastellessa mieltä moniulotteisena ilmiönä. Kaikki luonnossa on luonnollista.

4 Poikkeuksellisia tajunnan tiloja on toki kuvattu myös länsimaisessa psykologiassa esimerkiksi Maslowin, Jamesin ja Jungin toimesta (Walsh \& Shapiro 2006, 232-233; ks. Wilberg 2009).

5 Istumameditaatio voi nostaa esille myös traumamuistoja (Juvakka 2011, 50) ja sitä voidaan käyttää kokemusten tukahduttamisen välineenä (ks. Väänänen, Kortelainen, Saari tulossa). Kontemplatiiviset harjoitukset koulussa eivät yleensä mene tälle tasolle, mutta riski tähän on tiedostettava. 